\title{
Preliminary Analysis of the Antidiabetic Activity of Indonesian Polyherbal Formulation
}

\author{
Syamsudin Abdillah ${ }^{1}{ }^{*}$, Apriala Gita Lestari ${ }^{1}$, Priskila Monika ${ }^{1}$, Wahono Sumaryono ${ }^{2}$ and Kartiningsih Hisyam ${ }^{3}$ \\ 1Department of Pharmacology, Faculty of Pharmacy, Universitas Pancasila \\ JI. Srengseng Sawah, Jagakarsa, South Jakarta 12640, Indonesia; syamsudin.abdillah@gmail.com \\ 2Department of Biological of Pharmacy, Faculty of Pharmacy, Universitas Pancasila \\ J. Srengseng Sawah, Jagakarsa, South Jakarta 12640, Indonesia \\ ${ }^{3}$ Department of Pharmaceutical Technology, Faculty of Pharmacy, Universitas Pancasila \\ J. Srengseng Sawah, Jagakarsa, South Jakarta 12640, Indonesia
}

\section{Abstract}

This study aims to prepare polyherbal formulations and also analyze the antidiabetic potentials of the prepared polyherbal in animals. The ethanol extracts of the leaves of Smallanthus sonchifolius, Stevia rebaudiana, Syzygium polyanthum, and Camellia sinensis were used in this study. The extracts of the aforementioned plants were prepared in the ratio of 2:1:1:1. The formulation was tested for antidiabetic activity in vitro through the inhibition of alpha-glucosidase and in vivo using alloxan-induced diabetes in mice. The polyherbal has an inhibitory effect with the $\mathrm{IC}_{50}$ value of $26.23 \mu \mathrm{g} / \mathrm{mL}$ compared to acarbose (control) was $17.02 \mu \mathrm{g} / \mathrm{mL}$. The diabetic animals were observed to show an obvious decline in glucose level when compared with control $(\mathrm{P}<0.001)$ after treatment.

Keywords: Antidiabetic, Extract, Formulation, Glucose, Herb, Inhibition

\section{Introduction}

Diabetes Mellitus (DM) is a metabolic disorder attributed to the pancreas inability to produce enough insulin or the ineffective insulin utilization by the body. There are two main categories, type 1 and 2. The first is insulindependent, juvenile, or childhood-onset diabetes, and is based on the inadequate production of insulin ${ }^{1}$. While the other one is non-insulin-dependent or adult-onset diabetes (Type 2) because of the less efficiency of insulin hormone. According to WHO, the number of DM patient in Indonesia may increase by 21.3 million in 2030, while International Diabetes Federation predicted about 14.1 million raise in 2035 with type 2 diabetes constituting $90 \%$ of all cases ${ }^{2}$.

Based on characterization results, the extracts of yakon (Smallanthus sonchifolius), stevia (Stevia rebaudiana), and bay (Syzygium polyanthum) were subjected to further pharmacological screening. Polyherbal formulations contain multiple ingredients of different plants origin. Also, these products were used to enhance the effect or check the harmfulness of other ingested medications. They may also produce a synergetic effect due to the presence of the various constituents ${ }^{3}$. Polyherbal products were observed to be better with the extended therapeutic potentials when compared to single herbal medicines. Hence, this research aimed to carry out the medicinal preparation in form of polyherbal formulation using plants with known antidiabetic activity.

\section{Materials and Methods}

\subsection{Collection of Plants}

The proposed herbal drug (S. sonchifolius, S. rebaudiana, S. polyanthum, and Camellia sinensis) was collected from Balitro, Bogor, West Java. All of the used leaves were shadedried, made into powder with moderately coarse texture,

\section{*Author for correspondence}


and then stored in an airtight container. The powder was used for extraction later on. The plant specimens were identified and authenticated in Herbarium Bogoriense by Dr. Atik Retnowati, with the voucher number No 455/ IPH.1.01.

\subsection{Preparation of Polyherbal Formulation}

The dried leaves were ground into a powder and extracted using absolute ethanol of $80 \%$ for about 6 hours with a Soxhlet apparatus. These leaves were then dried at $60^{\circ} \mathrm{C}$ and were preserved at $4^{0} \mathrm{C}$. Furthermore, five formulations (F1-F5) were produced by mixing different ratios of pulverized plant materials. The constituents of the polyherbal formula included the leaves of yakon (S. sonchifolius), bay (S. polyanthum), stevia (S. rebaudiana), and tea (C. sinensis) plants with ratios as shown in Table 1.

Table 1. Composition of polyherbal formulation

\begin{tabular}{|c|c|c|c|c|}
\hline Formulations & $\begin{array}{c}\text { S. sonchifolius leaves } \\
(\mathbf{g})\end{array}$ & $\begin{array}{c}\text { S. polyanthum leaves } \\
\mathbf{( g )}\end{array}$ & $\begin{array}{c}\text { S. rebaudiana leaves } \\
\mathbf{( g )}\end{array}$ & $\begin{array}{c}\text { C. sinensis leaves } \\
(\mathbf{g})\end{array}$ \\
\hline F1 & 400 & - & 100 & 100 \\
\hline F2 & 200 & 200 & 100 & 100 \\
\hline F3 & 100 & 300 & 100 & 100 \\
\hline F4 & 300 & 100 & 100 & 100 \\
\hline F5 & - & 400 & 100 & 100 \\
\hline
\end{tabular}

\subsection{Alpha-Glucosidase Inhibitory Activity of Polyherbal Formulation (PF)}

The plant extracts $(50 \mu \mathrm{L})$ at various concentrations levels (10 to $1000 \mu \mathrm{g} / \mathrm{mL}$ ) were incubated with 10 $\mu \mathrm{L}$ of $\alpha$-glucosidase (maltase), yeast (Sisco Research Laboratories Pvt. Ltd.), and enzyme solution $(1 \mathrm{U} / \mathrm{mL})$ for $20 \mathrm{~min}$ at $37^{\circ} \mathrm{C}$ and $125 \mu \mathrm{L}$ of $0.1 \mathrm{M}$ phosphate buffer (pH 6.8). After 20 min of incubation, the reaction was initiated by adding $20 \mu \mathrm{L}$ of $1 \mathrm{M}$ pNPG (substrate) and then incubated for $30 \mathrm{~min}$. The reaction was terminated by adding $0.1 \mathrm{~N}$ of $\mathrm{Na}_{2} \mathrm{CO}_{3}(50 \mu \mathrm{L})$ and the final absorbance was calculated at $405 \mathrm{~nm}$ using Biotek multi-well plate reader ${ }^{5}$. Besides, acarbose drug was used as a positive control at different dilutions levels (10 to $1000 \mu \mathrm{g} / \mathrm{mL}$ ). The results of this analysis were expressed as percentage inhibition, calculated with the formula below:

Inhibitory activity $(\%)=(1-$ As/Ac $) \times 100$

where, As represents the absorbance of the test substance while Ac is the absorbance of control. The polyherbal combination with the IC50 value closer to the acarbose (control) was chosen for the animal testing ${ }^{4,5}$.

\subsection{Animals and Experimental Design}

\subsubsection{Induction of Experimental Diabetes}

The pancreatic $\beta$-cells of the experimental animals were damaged by inducing them with $150 \mathrm{mg} / \mathrm{kg}$ BW of alloxan injected intraperitoneally for 3 consecutive days. This process can result in reduced insulin production and hyperglycemia. The blood glucose level of the samples was examined before and after 72 hours of injection to observe the diabetes development. Furthermore, they were sustained for 5 days and the experimentation began on day six. This study, however, comprised only animals with a glucose concentration of less than $250 \mathrm{mg} / \mathrm{dL}$. The methods in this study were approved by the ethical committee of the Medicine Department of Universitas Indonesia with the certificate number: 0251/UN2.F1/ Etik/2018.

\subsubsection{Research and Development}

The diabetic samples were then grouped into five, comprising of six per unit, and treated with the chosen polyherbal formulation once daily for 22 days as presented below:

Group I (Normal healthy control): given only vehicle (CMC Na 0,5\%) 
Group II diabetic control: received vehicle only

Group III diabetic mice: received acarbose $6.5 \mathrm{mg} / \mathrm{kg}$ BW Group IV diabetic mice: received PF $100 \mathrm{mg} / \mathrm{kg}$ BW Group V diabetic mice: received PF 200 mg/kg BW Group VI diabetic mice: received PF 400 mg/kg BW And, then the blood glucose level of these animals was recorded on days 3,14 , and 22 of this experiment6,7.

\section{Results}

The plant formulation and their combined extracts are used as a drug of choice rather than individual herbs. The results of a preliminary test using in vitro alphaglucosidase enzyme inhibition method are shown in Table 2.

The results of antidiabetic activity test of combined herbal formula indicated that the IC50 value of F1 was $278.43 \mu \mathrm{g} / \mathrm{mL} ; 290.87 \mu \mathrm{g} / \mathrm{mL}$ for F2, $274.05 \mu \mathrm{g} / \mathrm{mL}$ for F3, $26.23 \mu \mathrm{g} / \mathrm{mL}$ for F4, and $216.14 \mu \mathrm{g} / \mathrm{mL}$ for F5. F4 has the closest $\mathrm{IC}_{50}$ to the control (acarbose), thus used in the next analysis.
Table 2. a-Glucosidase inhibitory effects of Polyherbal Formulation

\begin{tabular}{|c|c|}
\hline Formulations & $\begin{array}{c}\text { IC } \\
\mathbf{5 0} \text { values of a-glucosidase } \\
\text { inhibitory effects } \\
\text { of Polyherbal Formulation } \\
(\boldsymbol{\mu g} / \mathbf{m L})\end{array}$ \\
\hline Acarbose & 17.25 \\
\hline F1 & 278.43 \\
\hline F2 & 290.87 \\
\hline F3 & 274.05 \\
\hline F4 & 26.23 \\
\hline F5 & 216.14 \\
\hline
\end{tabular}

In vivo antidiabetic activity test of $\mathrm{F} 4$ was performed on alloxan-induced mice. The results of this study are shown in Table 3.

Based on this experiment, the polyherbal products developed a hypoglycemic effect at $400 \mathrm{mg} / \mathrm{kg}$ in a dose-related manner. This occurs mostly in normal and glucose-fasted loaded rats.

Table 3. Antidiabetic activity of Polyherbal Formulation in alloxan-induced type 2 diabetic mice

\begin{tabular}{|c|c|c|c|c|}
\hline \multirow{2}{*}{ Groups } & \multicolumn{4}{|c|}{ Blood Glucose Levels (mg/dl) } \\
\hline & Day 0 & Day 7 & Day 14 & Day 21 \\
\hline Normal Control & $87.23 \pm 2.24$ & $89.56 \pm 3.23$ & $86.67 \pm 3.45$ & $84.68 \pm 6.50$ \\
\hline Diabetic Control & $258.50 \pm 2.50$ & $260.35 \pm 5.60^{\mathrm{a}}$ & $287.50 \pm 5.80^{\mathrm{a}}$ & $293.20 \pm 6.75^{a}$ \\
\hline Acarbose $(6.5 \mathrm{mg} / \mathrm{kg})$ & $260.45 \pm 3.45$ & $215.10 \pm 6.50^{b}$ & $196.60 \pm 6.50^{b}$ & $99.40 \pm 4.5^{\mathrm{b}}$ \\
\hline $\begin{array}{l}\text { Polyherbal (PF) } \\
100 \text { mg/kg BW }\end{array}$ & $250.10 \pm 5.60$ & $212.20 \pm 5.60^{b}$ & $176.20 \pm 3.45^{b}$ & $160.45 \pm 5.60^{b}$ \\
\hline $\begin{array}{l}\text { Polyherbal (PF) } \\
200 \mathrm{mg} / \mathrm{kg} \mathrm{BW}\end{array}$ & $256.20 \pm 9.20$ & $204.60 \pm 6.45^{b}$ & $169.20 \pm 5.60^{b}$ & $120.30 \pm 4.50^{b}$ \\
\hline $\begin{array}{l}\text { Polyherbal (PF) } \\
400 \text { mg/kg BW }\end{array}$ & $260.45 \pm 10.23$ & $205.40 \pm 7.50^{b}$ & $150.80 \pm 7.60^{b}$ & $100.80 \pm 6.75^{b}$ \\
\hline
\end{tabular}

The values are mean $\otimes S E M, n=5,{ }^{a} p<0.001$ compared to a normal control group, and ${ }^{b} p<0.001$ compared to the diabetic control group

\section{Discussion}

Although most bioactive compounds can work on one target, they could also work on multi-targets. The pathology of diabetes mellitus is related to many metabolic pathways, multiple genes, and multiple functional proteins so it is imperative to discover drugs that come in the form of combination ${ }^{8}$. Various constituents in a formula or herb may enhance the bioavailability or the function of several targets instead of one to produce the synergistic effects ${ }^{9}$. These polyherbal formulations are produced with an herbal origin and are used to strengthen or check the effects of other herbal compounds. This product may have a wide spectrum of biological functions. Furthermore, these polyherbal products may produce synergetic action due to multiple ingredients and contain potentially agonistic/antagonistic pharmacological agents within themselves ${ }^{7}$. 
The study by Mahajan et al showed the polyherbal of C. caesia, E. alsinoide, C. lanatus, G. sylvestre and T. cordifolia, $W$ coagulans, and $C$ bonduct antidiabetic effect to rats induced by alloxan at $400 \mathrm{mg} / \mathrm{kg}$ of body weight. Our result is similar to that study, which showed a decrease of blood glucose level in the dose of $400 \mathrm{mg} /$ $\mathrm{kg}$ of body weight compared to positive control. Sabu et al evaluated the methanolic extract (75\%) of Terminalia chebula, Terminalia belerica, Emblica officinalis, and their combination named 'Triphala.' Oral administration of the extracts $(100 \mathrm{mg} / \mathrm{kg}$ body weight) reduced the blood sugar level in normal and in alloxan $(120 \mathrm{mg} / \mathrm{kg})$ diabetic rats significantly within $4 \mathrm{~h}$ and the daily administration of the drug produced a sustained effect ${ }^{10}$.

The research conducted by Aziz et al. using 95\% ethanol extract of Yakon leave (S. sonchifolius (Poepp. $\&$ Endl.) succeeded in isolating $\alpha$-glycosidase inhibitor compounds, which were the FOS group, nystose, with the $\mathrm{IC}_{50}$ value of $33.62 \mathrm{ppm}$, while the positive control for acarbose had $21.36 \mathrm{ppm}^{5}$. Habib et al. conducted an in vivo study of standardized yakon extract (S. sonchifolius) against $340 \mathrm{mg} / \mathrm{kg}$ BW and $6800 \mathrm{mg} / \mathrm{kg}$ BW doses of compounds in the FOS group. Furthermore, this was administered for 90 days in streptozotocin-induced rats and showed a decreased blood glucose and insulin levels with improved pancreatic function to near normal ${ }^{11}$. Genta et al. used this same extract, which was administered orally to diabetic rats similar to the aforementioned; also reduced the blood glucose level ${ }^{12}$. This extract equally causes the blood glucose level to decrease in diabetogenic subjects due to the presence of polyphenol compounds that act as antioxidants ${ }^{13}$. Other compounds found in the Yakon leaves were quercetin, ferulic, p-coumaric, caffeic, chlorogenic, and protocratic acids.

The research conducted by Widyawati et al. in Health Community Center, Medan, North Sumatra, Indonesia from 2010-2011 reported S. polyanthum (Wight) as the most commonly used herb in the management of diabetes mellitus traditionally ${ }^{14}$. The results showed the alpha-glucosidase enzyme inhibitory activity from the leaf extract, which was taken from several regions in Java Island. It showed that the water obtained had a better IC50 value of $51.10 \mu \mathrm{g} / \mathrm{mL}$ compared to those from West and East Java. Furthermore, the conducted isolation found several compounds in the flavonoid class, including quercetin, coniferin, juncusol, and retusine ${ }^{15}$. The medium-polar extract of $S$. rebaudiana leaves produced an obvious $(\mathrm{P}<0.01)$ dose-dependent decline in blood glucose level and body weight when administered orally (200 and $400 \mathrm{mg} / \mathrm{kg}$ ) for 10 days. However, the rats treated with glibenclamide and Stevia was later observed to gradually regain weight. The treatments done with Stevia extract was failed to cause hypoglycemia and loss of weight, yet the restoration of the pancreas' $\beta$-cells with the antagonizing $\beta$-necrotic action of alloxan was observed.

Previous studies reported the improvement of blood sugar level after feeding the green tea extract or the polyphenols, flavonoids, and catechins to chemicallyinduced hyperglycemia animals ${ }^{16}$. According to Shimizu et al. the hypoglycemic activity of Japanese tea in normal and streptozotocin-induced diabetic rats was identified as a polysaccharide. The bioactive constituents of tea, especially catechins, chlorogenic acid, caffeine, and the flavins, showed an inhibitory effect on a-glucosidase and $\alpha$-amylase activity ${ }^{17}$. Therefore, it has resulted in the decreased levels of glucose, lipid, metabolites, and albuminuria. Furthermore, the pronounced antihyperglycemic effect was observed based on synergistic actions of various effective ingredients in Polyherbal formulation. The declined glucose is due to elevation of glycogenesis or the increased entry of glucose molecules to various skeletal muscles ${ }^{18}$.

\section{Conclusion}

The polyherbal formulation is a potential antidiabetic agent; therefore, it becomes interesting to investigate the underlying action molecular mechanism(s) and longterm toxicity studies of different animal species. Besides, after the completion of preclinical studies, this herbal product needs to be tested on human DM patients to ascertain the therapeutic efficacy and safety.

\section{Acknowledgement}

This work was funded by the INSINAS grant (G1/118, 2020) of the Ministry of Research, Technology and Higher Education of the Republic of Indonesia (KEMENRISTEK DIKTI)

\section{References}

1. Skyler JS. Diabetes mellitus: Pathogenesis and treatment strategies. J Med Chem. 2004; 47:4113-7. https://doi.org/10.1021/jm0306273

2. World Health Organization. Geneva: WHO; 2008. Diabetes, Fact sheet no. 312. http://www.who.int/ mediacentre/factsheets/fs312/en/index.htmL.

3. Majeed A, Farooq S, Khan NA. Polyherbal formulations for treatment of diabetes: A Review. Intern Journ Scien Res and Rev. 2019; 8(2):520-2. 
4. Mahayasih PGM, ElyaB, HanafiM. Alpha-glucosidase inhibitory activity of Garcinia lateriflora blume leaves. J App Pharm Sci. 2017; 7(10):100-4. https:// doi.org/10.7324/JAPS.2017.71014

5. Aziz Z, Al Qisthi FH, Djamil R, Syamsudin, Yuliana ND, Simanjuntak P. Identifikasi senyawa penghambat enzim a-glukosidase dari ekstrak etanol 96\% daun yakon (Smallanthus sonchifolius (Poepp. \& Endl.) H. Robinson. Jurnal Kefarmasian Indonesia. 2019; 17(1):21-6. https://doi.org/10.35814/jifi.v17i1.652

6. Kapsea S, Andoa H, Fujiwaraa Y, et al.Effect of a dosing-time on quetiapine-induced acute hyperglycemia in mice. J Pharm Sci. 2017; 133:13945. https://doi.org/10.1016/j.jphs.2017.02.008

7. Joshi CJ, Priya ES,Venkataraman S. Hypoglycemic and anti-lipid peroxidative effects of a polyherbal formulation, Diakyur, in experimental animal models. Journal of Health Sciences. 2007; 53(6):7349. https://doi.org/10.1248/jhs.53.734

8. Li H, Zhao L, Zhang B, Jiang Y, Wang X, Guo, Y, et al. A network pharmacology approach to determine active compounds and action mechanisms of ge-genqin-lian decoction for treatmentof type 2 diabetes. Evid-Based Complement Altern Med. 2014; 49:84. https://doi.org/10.1155/2014/495840

9. Li S, Zhang B, Jiang D, Wei Y, Zhang, N. Herb network construction and co-module analysis for uncovering the combination rule of traditional Chinese herbal formulae. BMC Bioinform. 2010; 11:S6. https://doi. org/10.1186/1471-2105-11-S11-S6

10. Mahajan SM, Baviskar DT, Chaudhari PM. Antidiabetic activity of polyherbal formulation on alloxan induced diabetes. IOSR J Pharm Biol Sci. 2018; 13(1):1-6.

11. Habib NC, Barcellona CS, Honore' SM, Genta SB, Sa'nchez SS. Yacon roots (Smallanthus sonchifolius) improve oxidative stress in diabetic rats. J Pharm Biol. 2015; 53(8):1-11. https://doi.org/10.3109/1388 0209.2014.970285
12. Genta SB, Cabrera WM, Mercado MI, Grau A, Catalán CA, Sánchez SS. Hypoglycemic activity of leaf organic extracts from Smallanthus sonchifolius: Constituents of the most active fractions. ChemicoBiological Interactions. 2010; 185(2):143-52. https:// doi.org/10.1016/j.cbi.2010.03.004

13. Baroni S, Kemmelmeier FS, Caparroz-Assef SMR, Cuman KN, Bersani-Amado CA. Effect of crude extracts of leaves of Smallanthus sonchifolius (yacon) on glycemia in diabetic rats. Brazilian Journal of Pharm Scivol. 2008;44(3):521-30. https://doi. org/10.1590/S1516-93322008000300024

14. Widyawati T, Purnawan WW, Atangwho IJ, Yusoff NA, Ahmad M, Asmawi ZM. Anti-diabetic activity of Syzygium polyanthum (wight) leaf extract, the most commonly used herb among diabetic patients in Medan, North Sumatera, Indonesia. Int J Pharm Sci Res. 2015; 6(4):1698-04. https://doi.org/10.13040/ IJPSR.0975-8232.6(4).1698-04

15. Dewijanti ID, Mangunwardoro W, Dwiranti A, Hanafi M, Artanti N. Effects of the various source areas of Indonesia bay leaves (Syzygium polyanthum) on chemical content and antidiabetic activity. Biodiversitas. 2020; 21(3):1190-3. https://doi. org/10.13057/biodiv/d210345

16. Islam S. Phytomedicine effects of the aqueous extract of white tea (Camellia sinensis) in a streptozotocininduced diabetes model of rats. Euro J Integrative Med. 2011; 19(1):25-31. https://doi.org/10.1016/j. phymed.2011.06.025

17. Shimizu M, Wada S, Hayashi T, Arisawa M,Ikegaya K, Ogaku S, Yano S, Morita N.Studies on hypoglycemic constituents ofJapanese tea. Yakugaku Zasshi. 1988;108:964-70. https://doi.org/10.1248/ yakushi1947.108.10_964

18. Kasireddy PB, Kumar SA, Namratha S, Swathiz B, Manguluri P,Adapa V. Evaluation of antidiabetic efficacy of polyherbal formulation in experimentally induced hyperglycemic rats. Int J Res Pharm Chem. 2016; 6(4):750-8. 